\title{
PROJECT TRINIDAD
}

\section{DELTA SERIES NUMBERS 1, 2, AND 3 SOPRIS, COLORADO}

\author{
U. S. DEPARTMENT OF COMMERCE \\ NATIONAL OCEANIC AND ATMOSPHERIC ADMINISTRATION \\ NATIONAL OCEAN SURVEY
}

18, DECEMBER 1970
PREPARED FOR THE U. S. ATOMIC ENERGY COMMISSION NEVADA OPERATIONS OFFICE UNDER CONTRACT AT(29-2) - 746




\section{DISCLAIMER}

This report was prepared as an account of work sponsored by an agency of the United States Government. Neither the United States Government nor any agency Thereof, nor any of their employees, makes any warranty, express or implied, or assumes any legal liability or responsibility for the accuracy, completeness, or usefulness of any information, apparatus, product, or process disclosed, or represents that its use would not infringe privately owned rights. Reference herein to any specific commercial product, process, or service by trade name, trademark, manufacturer, or otherwise does not necessarily constitute or imply its endorsement, recommendation, or favoring by the United States Government or any agency thereof. The views and opinions of authors expressed herein do not necessarily state or reflect those of the United States Government or any agency thereof. 


\section{DISCLAIMER}

Portions of this document may be illegible in electronic image products. Images are produced from the best available original document. 


\section{LEGAL NOTICE}

This report was prepared as an account of work sponsored by the United States Government. Neither the United States nor the United States Atomic Energy Commission, nor any of their employees, nor any of their contractors, subcontractors, or their employees, makes any warranty, express or implied, or assumes any legal liability or responsibility for the accuracy, completeness or usefulness of any information, apparatus, product or process disclosed, or represents that its use would not infringe privately-owned rights.

Available from the

National Technical Information Service

U. S. Department of Commerce

Springfield, Virginia 22151 
PROJECT TRINIDAD

DELTA SERIES NUMBERS 1, 2, AND 3

SOPRIS, COLORADO

U. S. DEPARTMENT OF COMMERCE

NATIONAL OCEANIC AND ATMOSPHERIC ADMINISTRATION

NATIONAL OCEAN SURVEY

Kenneth W. King, Chief

Special Projects Party

Las Vegas, Nevada

December 18, 1970 
CONTENTS

INTRODUCTION . . . . . . . . . . . . . . . . 1

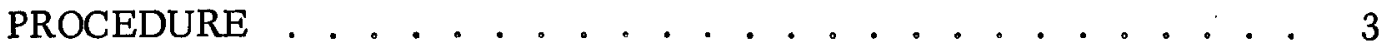

1. Seismograph Stations . . . . . . . . . . . 3

2. Instrumentation ... . . . . . . . . . . 5

RESULTS . . . . . . . . . . . . . . . . . . 7

TABLES

Table I List of Pull Tests . . . . . . . . . . . . 8

Table II Project Trinidad Series :D" Number 1 Peak

Surface Velocities . . . . . . . . . . . 9

- Table III Project Trinidad Series. "D" Number 2 Peak

Surface Velocities . . . . . . . . . . 10

Table IV Project Trinidad Series "D" Number 3 Peak

Surface Velocities . . . . . . . . . . . 11

Table V Maximum Free-field Accelerations Measured at

Station 6 Delta Series. Numbers 1, 2, and 3 . . . 12

\section{FIGURES}

Figure 1. Map of Colorado .. . . . . . . . .. . 13

Figure 2 Location Map of Project Trinidad, NOS Seismic

Stations . . . . . . . . . . . . 14

Figure 3 Map of Town of Sopris with Stations 2, 3, 4, 5, and

6 Shown . . . . . . . . . . 15

\section{PHOTOGRAPHS}

Photo \#1 Sopris, Colorado . . . . . . . . . . 16

Photo \#2 NOAA/NOS Seismic Recording Van . . . . . . 16

Photo \#3 Station 1, Test House \#1, Looking Northwest . . 17

Photo \#4. Station 1, Test House \#1, Looking Northeast . . . 17

Photo \#5 Station 2, Test House \#2, Looking Northwest . . 18

Photo \#6 Station 2, Test House \#2, Seismometers on

First Floor, Center of Building . . . . . . 18

Photo \#7 Station 2, Test House \#2, November 17, 1970

Seismometers Located Second Floor, Center

of Building . . . . . . . . . . . . . 19 
PHOTOGRAPHS (cont'd)

Photo \#8 Station 2, Test House \#2, November 19, 1970, Seismometer Location on Second Floor Center . . . . . 19

Photo \#9 Station 3, Test House \#3, Looking Southeast . . . . . . 20

Photo \#10 Station 3, Test House \#3, Typical Pull-Test Setup . . . . . . . . . . . . . . 20

Photo \#11 Station 3, Test House \#3, Seismometer Location for November 19, 1970, First Floor, North Side of House . . . . . . . . . . . . ..... 21

Photo \#12 Station 3, Test House \#3, Seismometer Location for November 19, 1970, First Floor Center of House . . . . 21

Photo \#13 Station 3, Test House \#3, Seismometer Location for November 19, 1970, First Floor South Side of the House. . ................... 21

Photo \#14 Station 4, Test House \#4, Looking Southeast . . . . . 22

Photo \#15 Station 4, Test House \#4, Seismometer Location Center Chimney of House \#4 . . . . . . . . 22

Photo \#16 Station 4, Test House \#4, Seismometer Location Southeast Chimney of House \#4 . . . . . . . . . 22

Photo \#17, Station 4, Test House \#4, Seismometer Location North Side of House : . . . . . . . . . . . . 23

Photo \#18 Station 4, Test House \#4, Seismometer Location South Side of House . . . . . . . . . . . . 23

Photo \#19 Station 4, Test House \#4, Typical Pull Test Setup . • . 23

Photo \#20 Station 5, Looking North at Free-standing Chimney .................. 24

Photo \#21 Station 5, Collapsed Chimney After Several Pull Tests ................. 24

Photo \#22 Station 6, (Free-field Station) Uncovered Accelerograph . . : . . . . . . . . . 24

DISTRIBUTION . . . . . . . . . . . . 。 . 。..... 25 


\section{INTRODUCTION}

The Delta Series experiments are part of Project Trinidad, a program conducted by the U. S. Army Engineer Nuclear Cratering Group (NCG). . The objectives of Project Trinidad are to further the capability of using chemical explosives to economically and rapidly excavate large quantities of earth and rock, and to acquire information about the ancillary effects of cratering detonations. Project Trinidad is located approximately six miles southwest of Trinidad, Colorado (see Figure 1).

Project Trinidad consists of four interdependent series of experiments: A, B, C, and D Series. A, B, and C Series were completed between July and October 1970. The first three experiments of the four planned events in the Delta (D) series were detonated on November 17, 18, and 19, 1970, while the fourth is scheduled for December. The four detonations of Series D consisted of Delta. \#l, a single row (five one- ton charges) through varying terrain; Delta \#2, a single row (five oneton charges) on a sidehill, Delta \#3, a double row ( one row had six tons while the other had 12 tons) on a sidehill with a time delay (15 milliseconds) between detonation of the two rows; and Delta \#4, a double row (40 tons) through varying terrain. The purposes of the first three experiments of Series D were to further the study of excavation with high explosives and its side effects and to define the uphill slope of the crater, while the purpose of the fourth experiment is an attempt to provide a railroad cut 400 feet long and 40 feet wide along the relocated alignment of the Colorado and Wyoming Railroad (Figure 2). 
The locations of the four experiments are shown on Figure 2. The first three experiments were located approximately 0.7 miles West-Southwest of the abandoned town of Sopris, Colorado.

The National Ocean Survey (NOS) (formerly the U.S. Coast and Geodetic Survey) instrumented for the Atomic Energy Commission (AEC) single family residential structures in Sopris, Colorado during the first three experiments of Series D and during the pull tests conducted by John A. Blume and Associates Research Division (JABARD) before and after each experiment. The purposes of instrumenting the structures were twofold: (1) to record the structural response effects of nearby high-explosive cratering experiments and (2) to determine the resonant periods of the structures and to detect any period shifts before and after each experiment. The purpose of this report is to give the results of the field effort of the special Projects Party whose members were Fred Ellis, Richard Navarro, and John West and to present preliminary data from the records.

Richard Navarro, Geophysicist 


\section{PROCEDURE}

\section{Seismograph Stations}

The National Ocean Survey's participation in the first three experiments of Series "D" of Project Trinidad involved the instrumentation of six stations: four singlefamily structures, one free-standing chimney, and a free field station, all located in the abandoned town of Sopris, Colorado. Figures 2 and 3 show the general locations of the six stations instrumented. Photographs 1 through 22 show all stations and their seismometer locations.

Station 1 (Test House \#l) was a one-story green adobe house nearest to ground zero, while Station 2 (Test House \#2) was a two-story frame house. Station 3 (Test House \#3) was a one-story pink stucco house and Station 4 (Test House \#4) was a one-story. concrete house. Station 5, a free-standing chimney, was located north of Station 2. Station 6, the free-fïeld station, was an accelerograph anchored to a sidewalk near the center of town.

Twenty-four instrument channels from three separate systems were utilized. Eighteen channels recorded velocities in five structures while a six-channel accelerograph measured direct particle accelerations on the ground. The eighteen velocity channels were provided from two systems, a six-channel and twelve-channel system. Generally the seismometers of the twelve-channel system remained in one place but those of the six-channel system were moved from House \#1 to House \#4 for Delta Number 3 . Stations 2, 3, and 6 recorded the three experiments while Stations 4 and 5 recorded one experiment。 
Station 1 recorded the first two experiments and Stations 4 and 5 recorded the last one. Each station with the exception of Stations 2 and 5 were instrumented with six channels. Station 2 was instrumented with five channels while Station 5 was instrumented with one horizontal seismometer located on the top of the free-standing chimneỳ.

As shown on Table I, 14 pull tests were conducted on structures at Stations 1, 2, 3,4 , and 5 . An average of three pull tests per station was made during three days of testing from November 17 through 19. JABARD made 14 previous pull tests which were recorded only on their portable blastmeter. Pull forces varied generally between 500 and 1500 pounds. The first pull test was used to determine gain settings for subsequent pull tests. In general, the seismometer locations remained the same during the pull tests and during the recording of the experiments. The seismometers at each station recorded at least one experiment in addition to the particular pull tests conducted on the structures.

Stations $1,2,3,4$, and 5 recorded on magnetic tape and visible recorders, while Station 6 recorded on twelve-inch photographic paper. Two of the six channels located on the top levels of Stations 1 and 4 recorded on a two-pen visible recorder. The entire six channels were recorded on magnetic tape. All channels from Stations 2 and 5 recorded on a twelve-channel visible recorder as well as on a magnetic-tape recorder. Stations 1, 4 and 5 recorded the three shots and all pull tests at two gains separated by $12 \mathrm{db}$. Station 6 recorded the three shots with two levels separated by a factor of three. All seismometers in the structures were oriented in directions parallel to the major and minor axes of the building. The accelerograph was oriented at 255 degrees. 


\section{Instrumentation}

Two types of seismograph systems were used on Project Trinidad, the L-7 velocity system and the accelerograph. The L-7 system is a compact and versatile velocity seismograph capable of recording on magnetic tape and visible recorders ground motions over a broad dynamic range and bandwidth. The $\mathrm{L}-7$, with an absolute sensi tivity of 400 volts peak to peak per centimeter per second vector at $36 \mathrm{db}$, has a flat velocity response over a frequency spectrum from $0.1 \mathrm{~Hz}$ to $100 \mathrm{~Hz}$. The $\mathrm{L}-7$ available in recording configurations of three channels, six channels, and twelve channels, has the capability to field calibrate the seismometers, amplifiers, tape

recorders, and power supply. A six-channel $L-7$ and twelve-channel $\mathrm{L}-7$ with groups of three seismometers, one vertical and two horizontals, were used on the project. The moving coil seismometer has a natural frequency of $1.875 \mathrm{~Hz}$ and 10 times critical damping. The L-7 data was recorded on magnetic tape, a visible two-pen Clevite Brush recorder and a visible twelve-channel CEC datagraph. The recorded signals are correlated with real time through a Chronolog time-code generator which was synchronized with WWV time.

The standard accelerograph contains three accelerometers and three displacement meters which measure direct motion in three directions of a Cartesian coordinate system. The modified accelerograph used on this project had two sets of accelerometers, each set having a different sensitivity. An optical-mechanical system of mirrors recorded the data from the seismometers on light sensitive strip chart paper and the paper was driven at a constant speed of $16 \mathrm{~cm} / \mathrm{sec}$. A relay provided half second breaks on both edges of the record. 


\section{RESULTS}

Good quality velocity and acceleration records were obtained from the three experiments of Series D and from the 14 pull tests. All stations operated successfully and recorded data on either visible records, magnetic tape,or photographic paper. The first arrivals on the accelerograph record of Delta \#l were not recorded.

Tables II, III, and IV list the maximum recorded peak surface velocity values with their corresponding periods from the Project Trinidad Series D experiments numbers 1,2 , and 3 , respectively. Also given on the three tables are scaled distances from the center of the row charges to each station, date and time of detonations, and orientation and location of each seismometer. Table IV lists the maximum peak particle accelerations with corresponding periods recorded at Station 6 ( free-field site) from the three Delta experiments.

In general the peak ground motions from the recorded experiments were below predicted values. The maximum free-field peak particle acceleration was recorded at Station 6 from Delta \#3 (Table V). The maximum recorded acceleration was $0.024 \mathrm{~g}$ with a period of $0.16 \mathrm{sec}$. 
Motion induced to the structures by the experiments was either equal to or greater by as much as 30 percent than the motion induced by any of the pull tests. The natural fundamental periods of all structures on which pull tests were conducted appear to lie between $0.09 \mathrm{sec}$ and $0.18 \mathrm{sec}$ (Table I). Further analysis of magnetic tape data for period and damping determinations will be performed by JABARD and reported in a subsequent report. 
TABLE I LIST OF PULL TESTS

\begin{tabular}{|c|c|c|c|c|c|}
\hline $\begin{array}{c}\text { Test } \\
\text { Numbers } \\
\text { NOS/JABARD) }\end{array}$ & $\begin{array}{l}\text { STATION } \\
\text { Number }\end{array}$ & $\begin{array}{l}\text { DATE } \\
(1970)\end{array}$ & $\begin{array}{l}\text { FORCE } \\
\text { (pounds) }\end{array}$ & $\begin{array}{l}\text { Direction } \\
\text { of } \\
\text { Pull }\end{array}$ & $\begin{array}{l}\text { Preliminary } \\
\text { Fundamental } \\
\text { Period of } \\
\text { Structure } \\
\text { Major Axis } \\
\quad \text { (sec) } \\
\end{array}$ \\
\hline $1 / 15$ & 2 & 17 Nov。 & 900 & East & 0.18 \\
\hline $2 / 16$ & 23 & $17 \mathrm{NoY}_{0}$ & 750 & East & \\
\hline $3 / 17$ & 2 & $17 \mathrm{Nov}$ & 1400 & East & \\
\hline$-4 / 18$ & 3 & 17 Nov. & .725 & North & 0.14 \\
\hline $5 / 19$ & 3 & 17 Nov. & 1025 & North & \\
\hline $6 / 20$ & 1 & $17 \mathrm{Nov}_{0}$ & 1025 & South & 0.10 \\
\hline $7 / 21$ & 1 & 17 Nov。 & 950 & South & \\
\hline $8 / 22$ & 1 & 17 Nov. & 875 & South & $\therefore$ \\
\hline $9 / 23$ & 4 & 18 Nov. & 575 & South. & 0.09 \\
\hline $10 / 24$ & 4 & $18 \mathrm{Nov}$. & 825 & South & \\
\hline $11 / 25$ & 4 & $18 \mathrm{Nov}_{\mathrm{o}}$ & 1025 & South & \\
\hline $12 / 26$ & 3 & $18 \mathrm{Nov}^{\circ}$ & $1100 / 800$ & North & 0.14 \\
\hline $13 / 27$ & 5 & 19 Nov. & $\begin{array}{l}\text { Handpulled } \\
\text { on rope unde } \\
\text { tension } \\
\end{array}$ & South & 0.17 \\
\hline $14 / 28$ & 5 & 19 Nov. & $\begin{array}{c}700 \\
\text { collapsed) }\end{array}$ & South & \\
\hline
\end{tabular}


NATIONAL OCEANIC AND ATMOSPHERIC ADMINISTRATION

NATIONAL OCEAN SURVEY

SPECIAL PROJECTS PARTY

Las Vegas, Nevada

TABLE II PROJECT TRINIDAD, SERIES "D" NUMBER 1 PEAK SURFACE VE LOCITIES

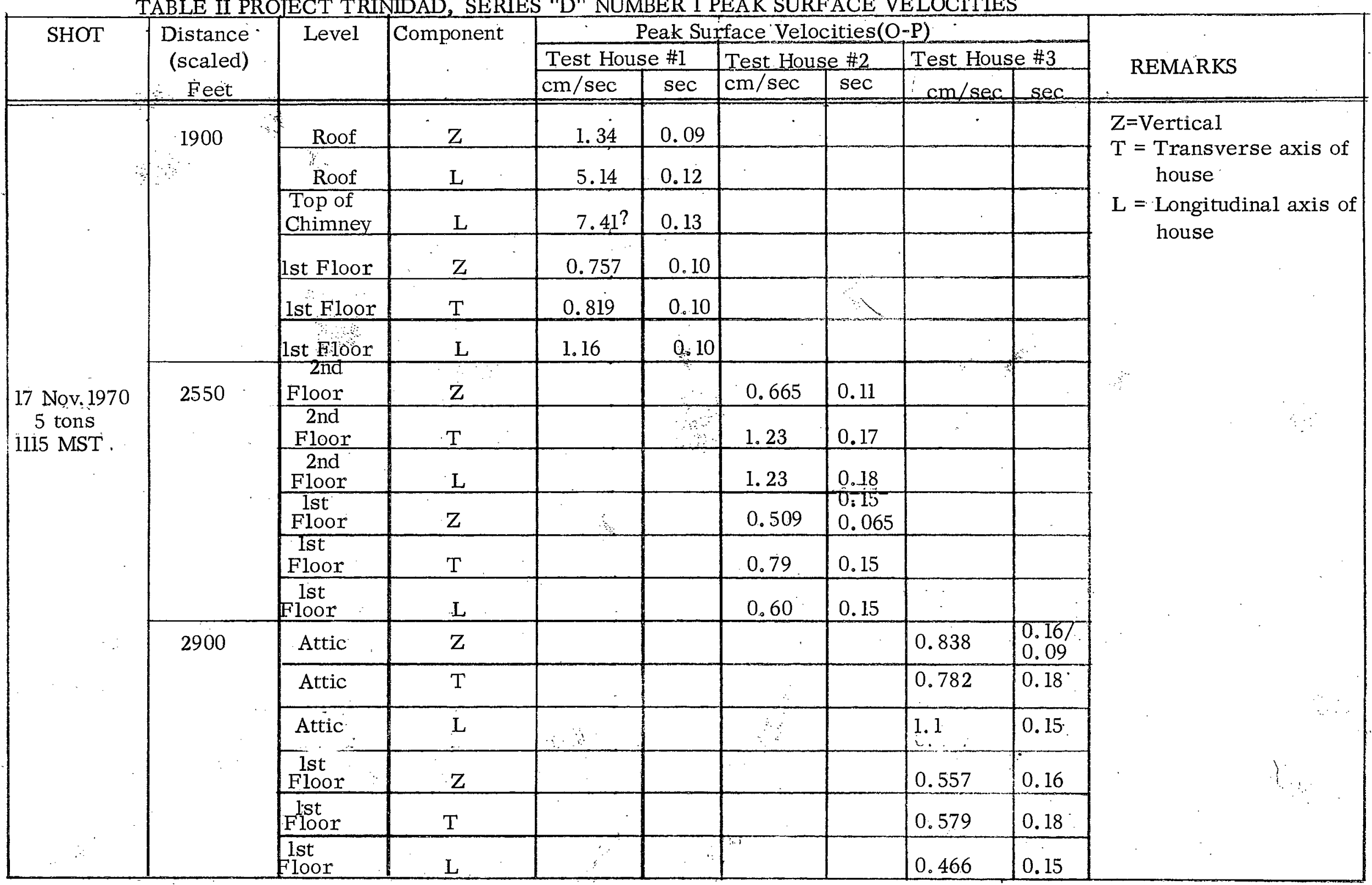


NATIONAL OCEANIC AND ATMOSPHERIC ADMINISTRATION

NATIONAL OCEAN SURVEY

SPECIAL PROJECTS PARTY

LAS VEGAS, NEVADA

TABLE III PROIECT TRINIDAD, SERIES "D" NUMBER 2 PEAK SURFACE VELOCITIES

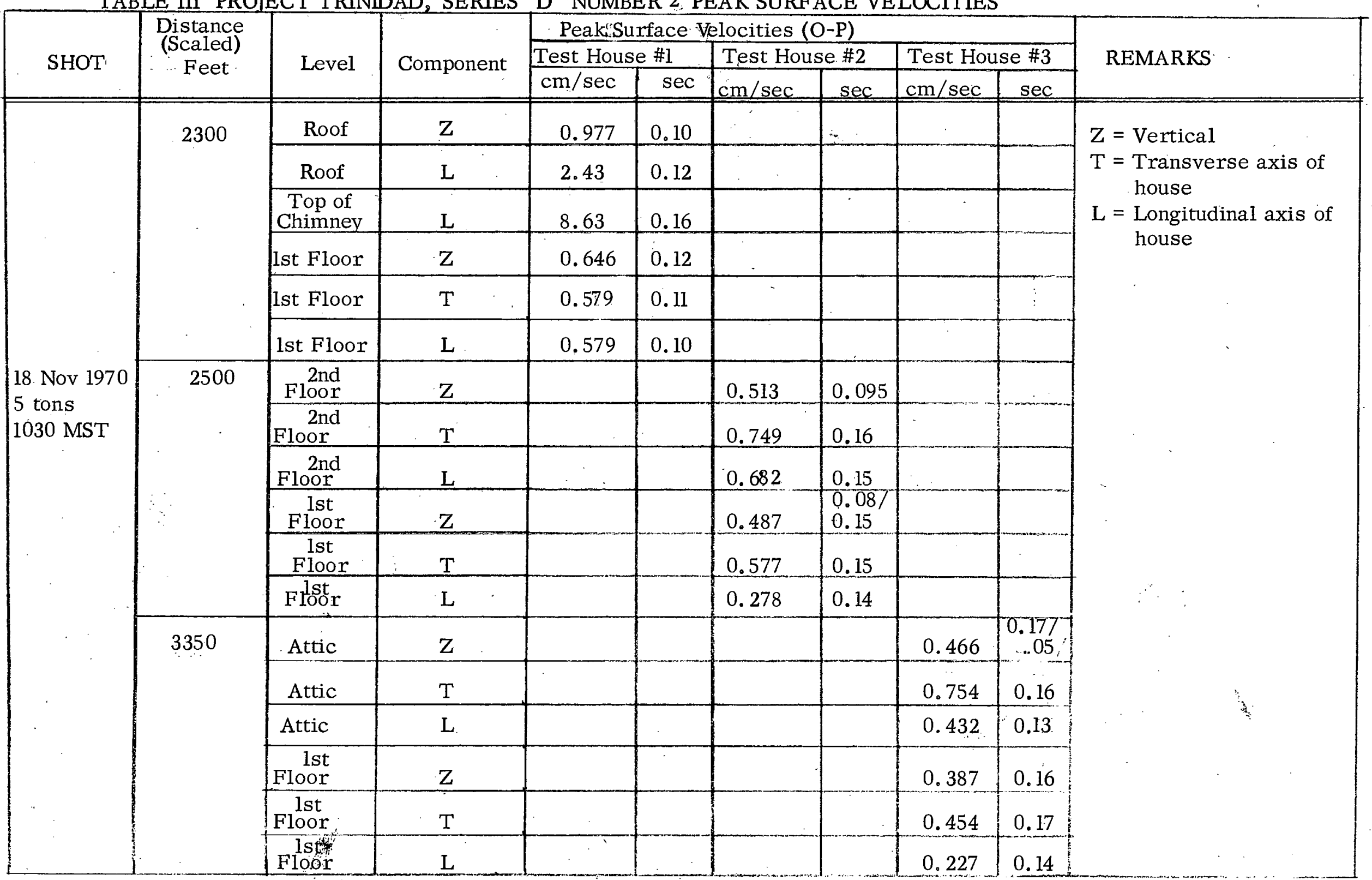


NATIONAL OCEANIC AND ATMOSPHERIC ADMINISTRATION

NATIONAL OCEAN SURVEY

SPECIAL PROJECTS PARTY

LAS VEGAS, NEVADA

TABLE IV PROJECT TRINIDAD, SERIES "D" NUMBER 3 PEAK SURFACE VELOCITIES

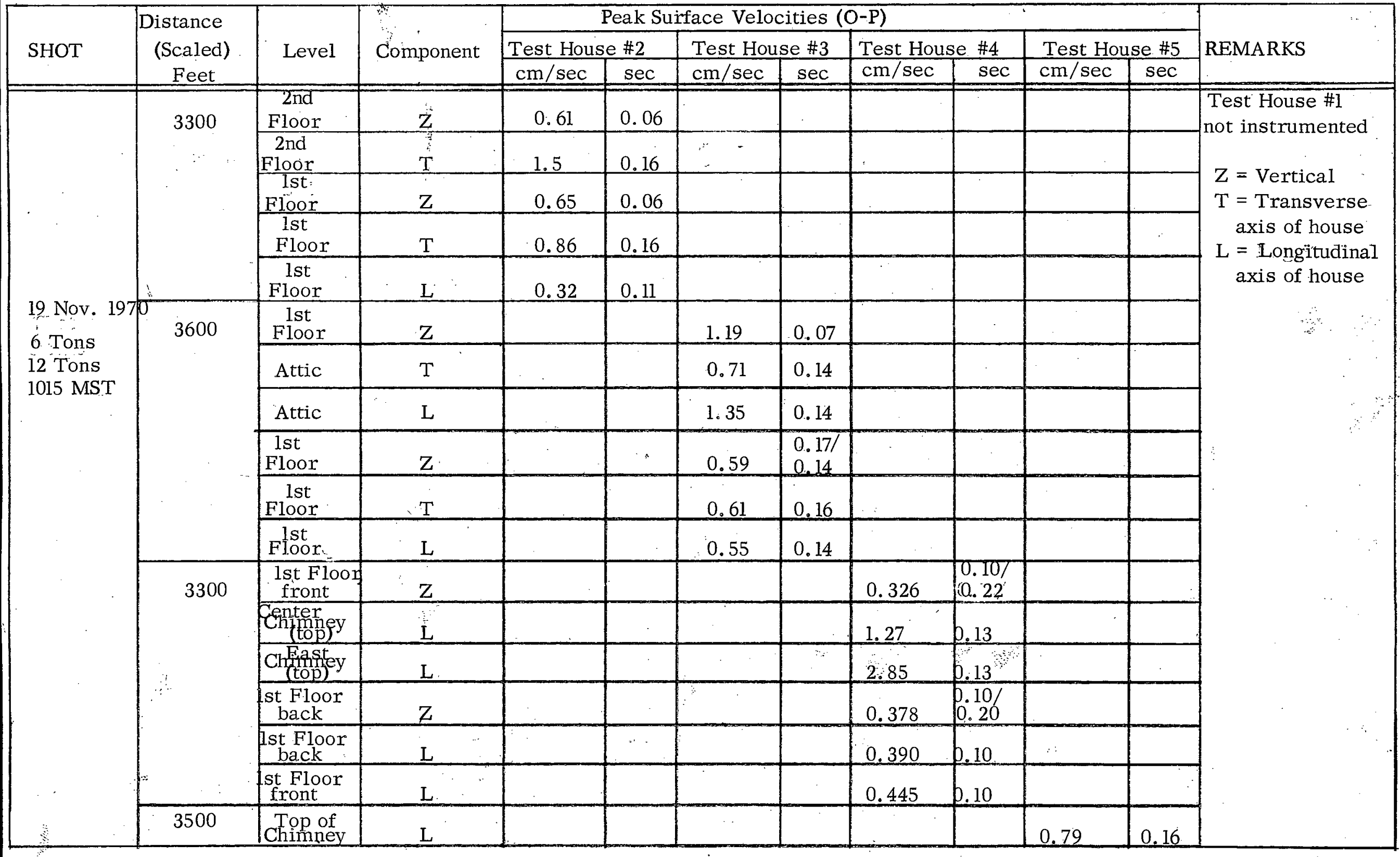

$-11-$ 


\section{NATIONAL OCEANIC AND ATMOSPHERIC ADMINISTRATION NATIONAL OCEAN SURVEY \\ SPECLAL PROJECTS PARTY \\ LAS VEGAS, NEVADA}

TABLE V MAXIMUM FREE-FIELD ACCELERATIONS MEASURED AT STATION \#6, DELTA SERIES NUMBERS 1,2 , and 3

\begin{tabular}{|c|c|c|c|c|c|c|}
\hline EXPERIMENTS & \multicolumn{2}{|c|}{ DELTA \#I } & \multicolumn{2}{|c|}{ DELTA \#2 } & \multicolumn{2}{|c|}{ DELTA \#3 } \\
\hline $\begin{array}{l}\text { Scaled distance from } \\
\text { center of row charges } \\
\text { to Station \#6 (feet) }\end{array}$ & \multicolumn{2}{|l|}{2800} & \multicolumn{2}{|c|}{3300} & \multicolumn{2}{|l|}{3500} \\
\hline CÖMP. & $\begin{array}{l}\text { Accel.* } \\
\mathrm{g}\end{array}$ & $\begin{array}{l}\text { Per. } \\
\text { sec }\end{array}$ & $\begin{array}{c}\text { Accel. } \\
\mathrm{g}\end{array}$ & $\begin{array}{l}\text { Per. } \\
\text { sec }\end{array}$ & $\begin{array}{l}\text { Accel. } \\
\mathrm{g}\end{array}$ & $\begin{array}{l}\text { Per. } \\
\text { sec }\end{array}$ \\
\hline $\begin{array}{l}\text { Verțical } \\
\text { (z) }\end{array}$ & $0.011 ?$ & 0.09 & 0.0088 & 0.15 & 0.0093 & 0.05 \\
\hline $255^{\circ}(\mathrm{R})$ & $0.021 ?$ & 0.13 & 0.021 & 0.16 & 0.014 & 0.15 \\
\hline $345^{\circ}(T)$ & $0.011 ?$ & 0.13 & 0.013 & 0.15 & 0.024 & 0.16 \\
\hline
\end{tabular}

* First arrivals lost on Delta \#1, maximums questionable.

Abbreviations:

$$
\begin{aligned}
& \text { Accel = Acceleration, } g \\
& \text { Comp }=\text { Component } \\
& \text { Per }=\text { Period } \\
& R=\text { Radial } \\
& T=\text { Transverse } \\
& \mathrm{Z}=\text { Vertical }
\end{aligned}
$$




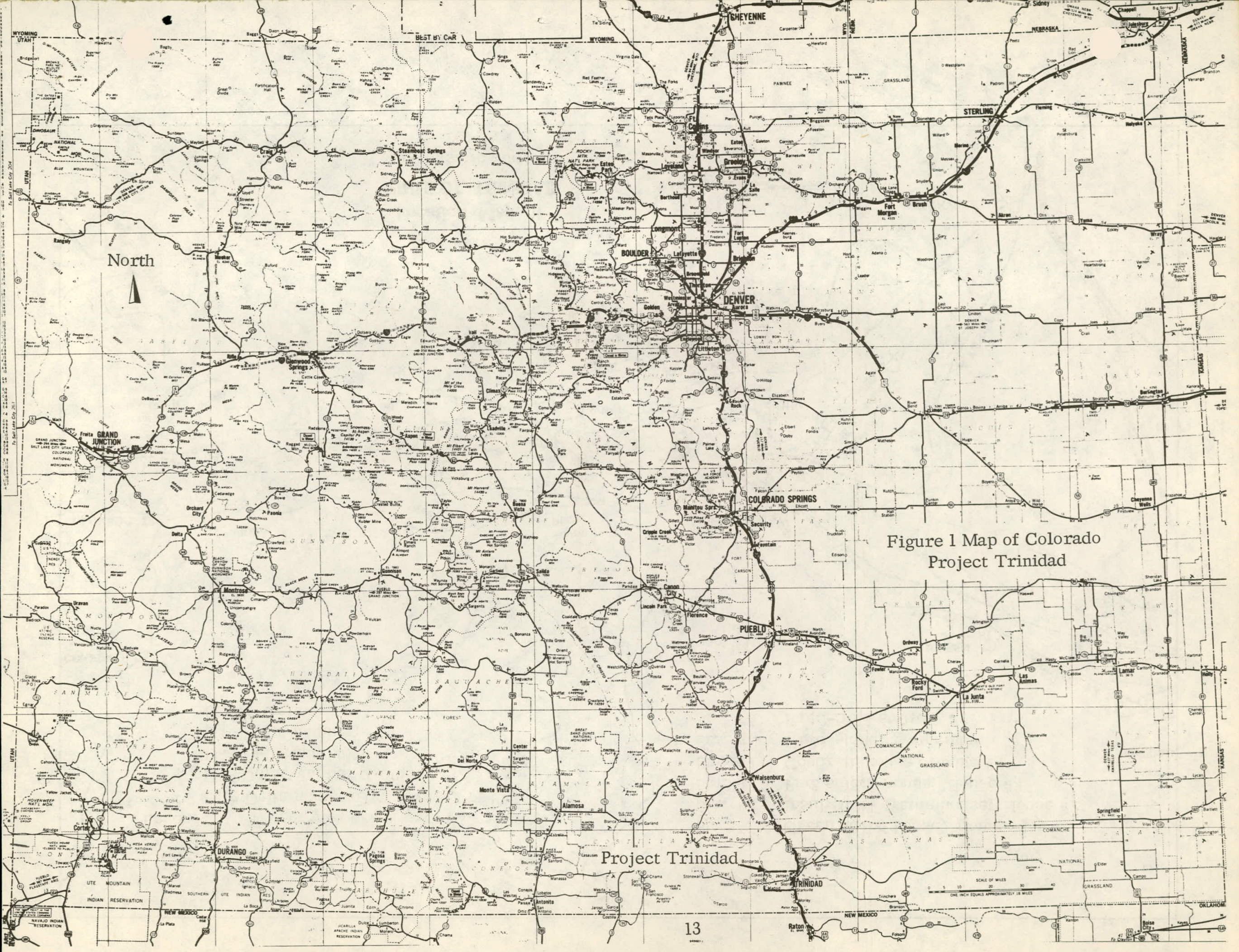




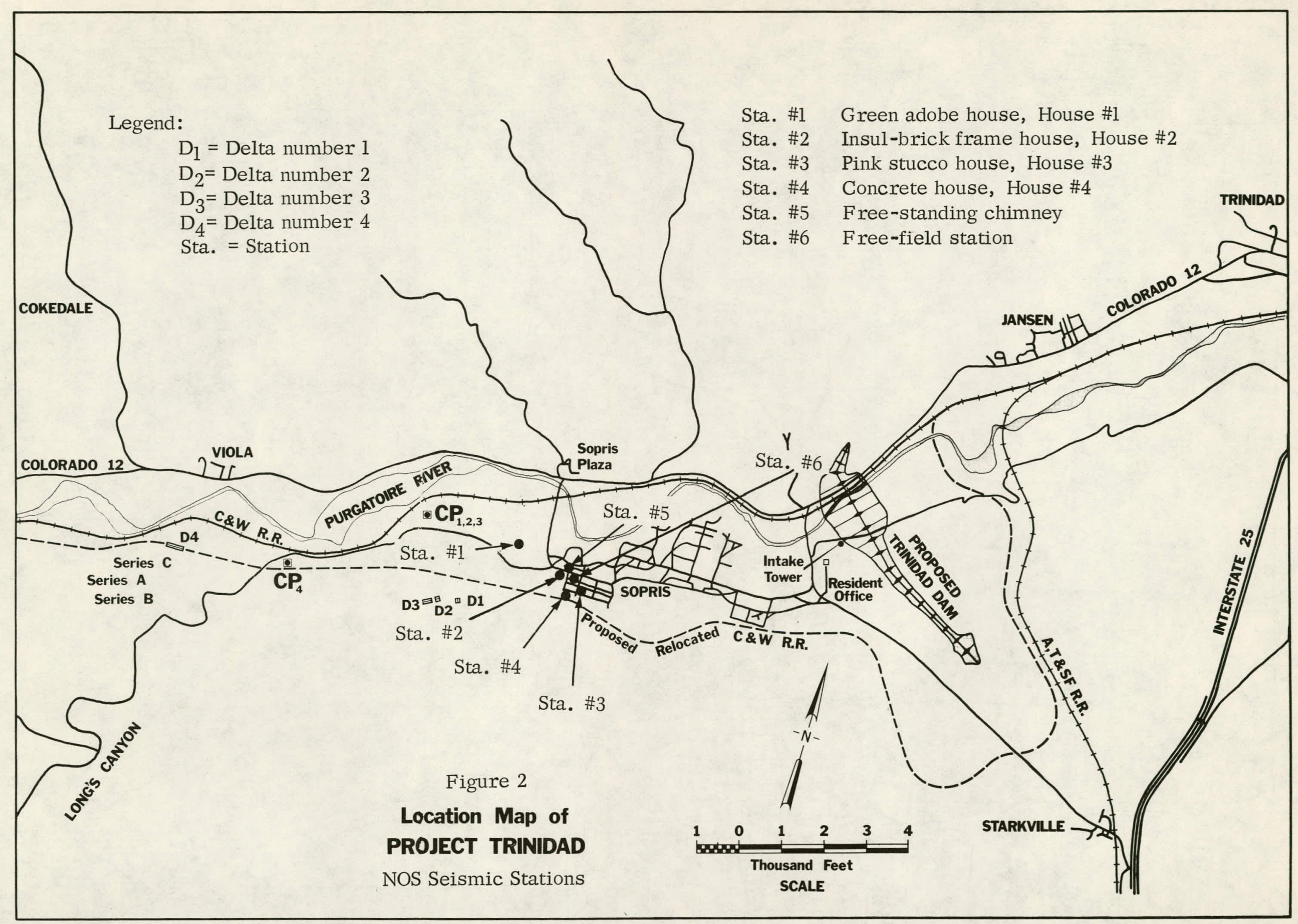




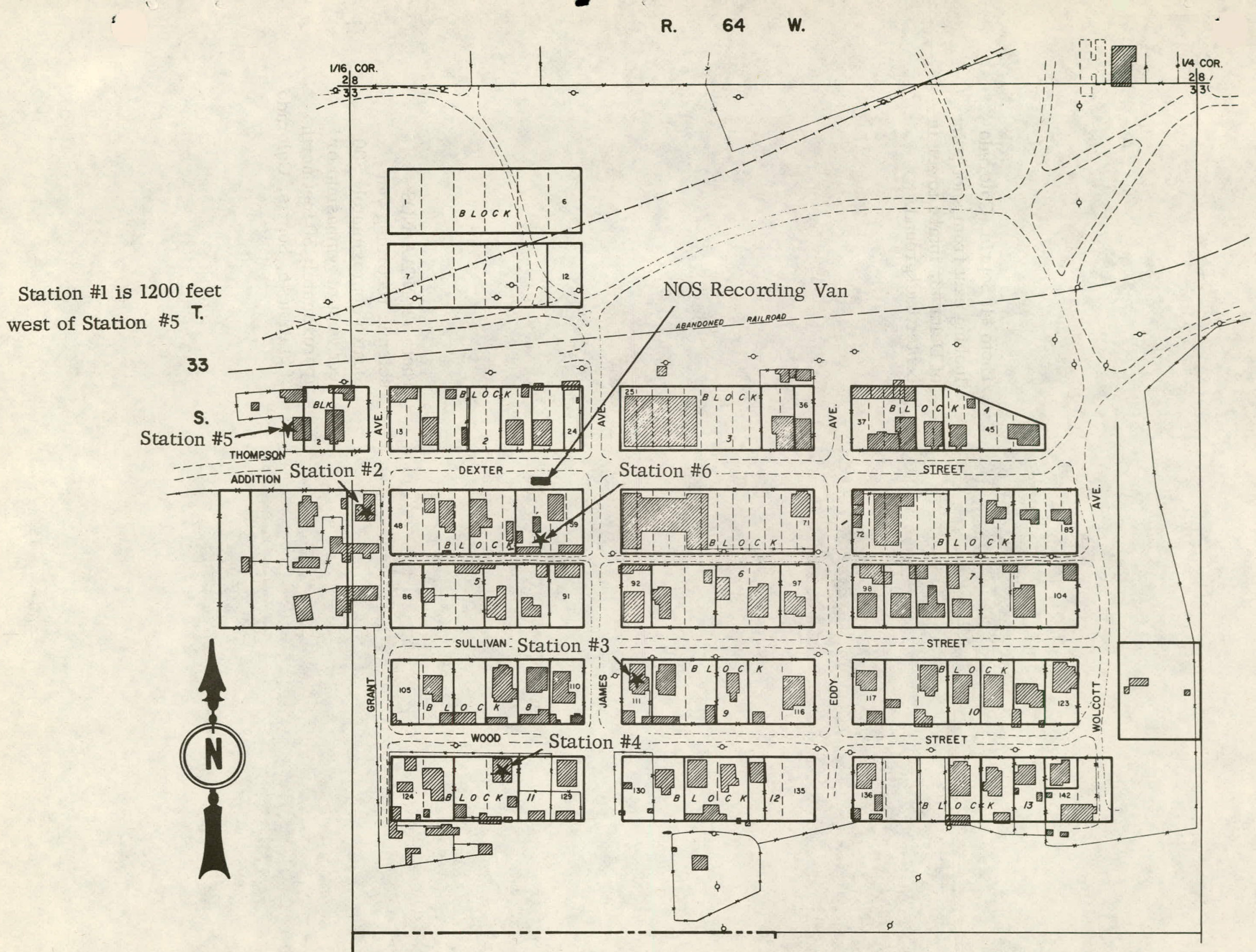

Figure 3 Town of Sopris with Stations 2, 3, 4,5, and 6 shown 

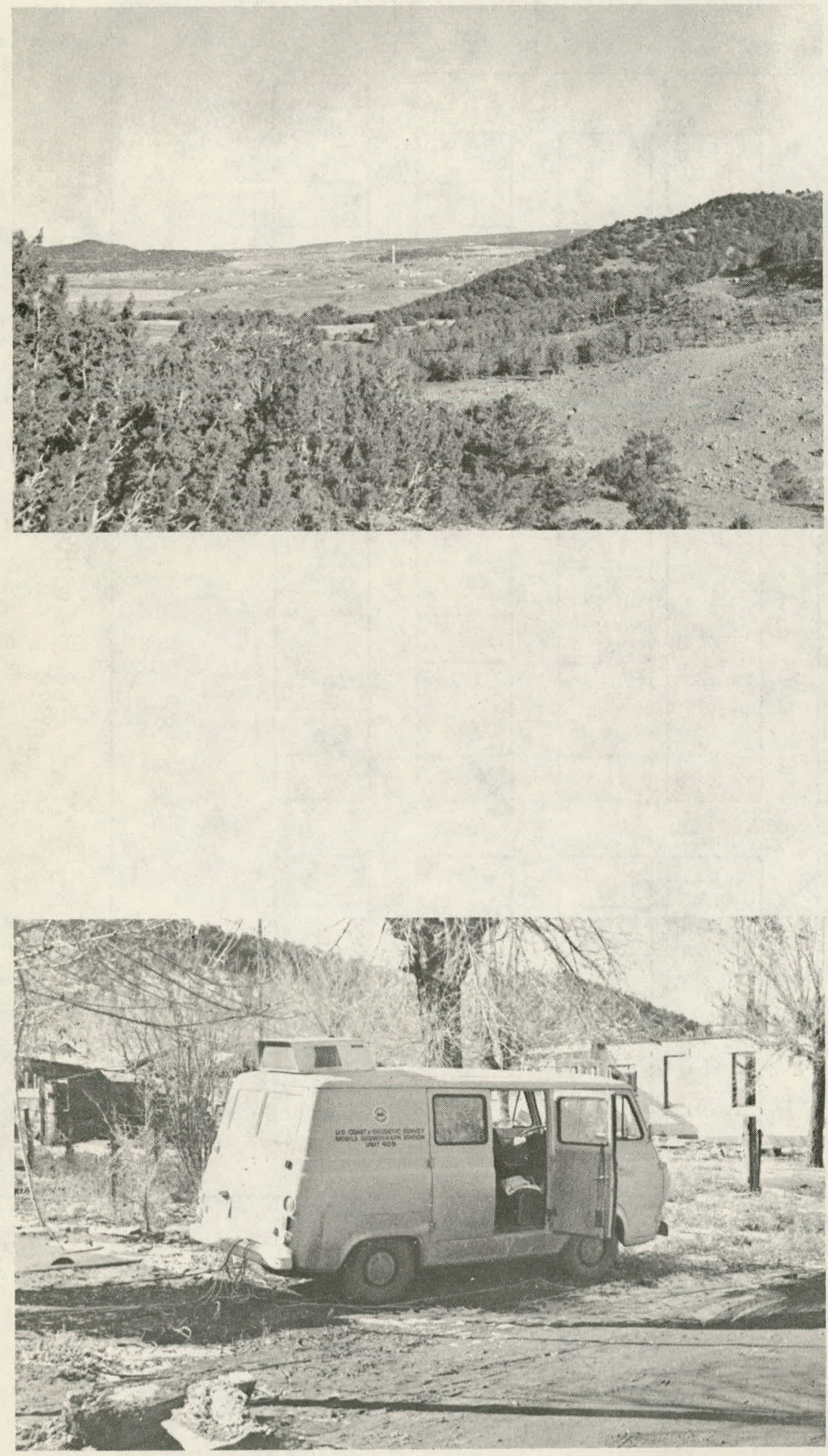

Photo \#1: Sopris, Colorado looking east from shot point of Delta \#3, intake tower in center background.
Photo \#2: NOAA/NOS

seismic recording van

located approximately 500

feet west of gymnasium or approximately 50 feet north of Station \#6, Sopris, Colorado 


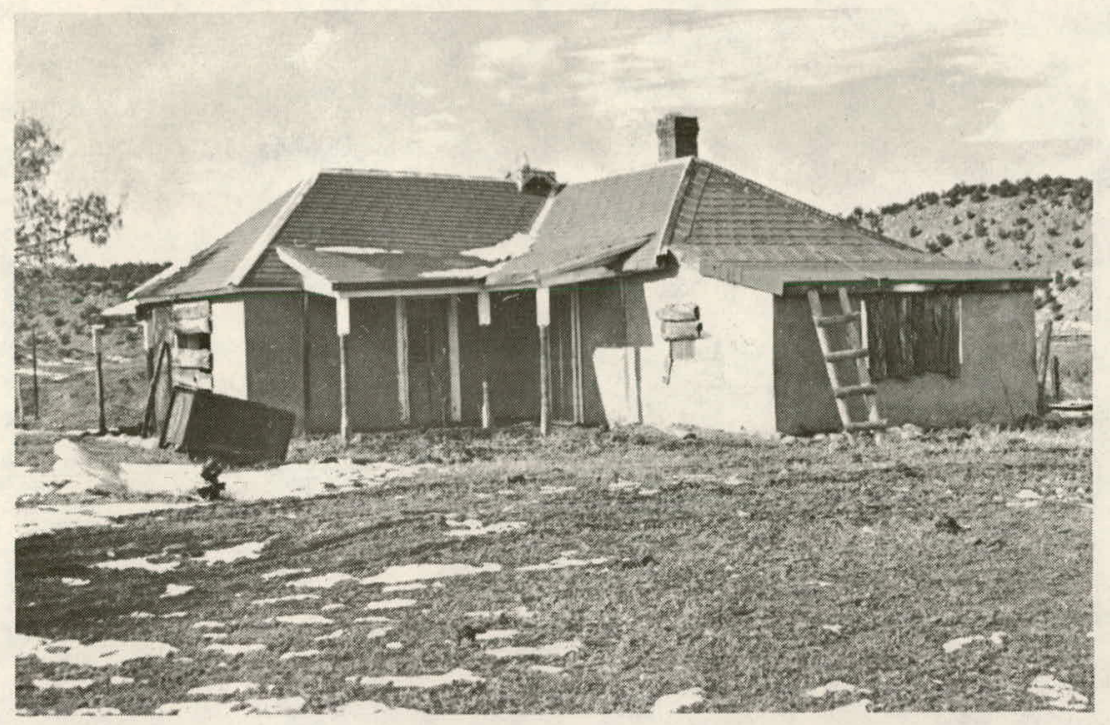

Photo \#3: Station \#1, Test House \#1, looking northwest.

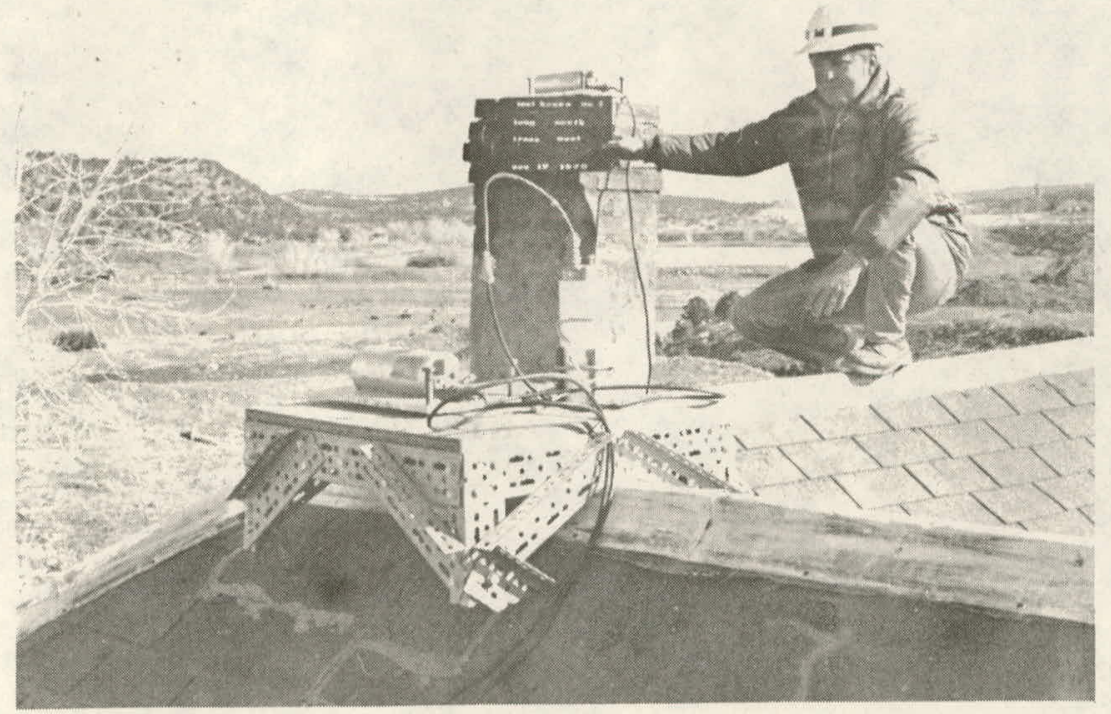

Photo \#4: Station \#1, Test House \#1, looking northeast. Seismometers on roof and chimney. 

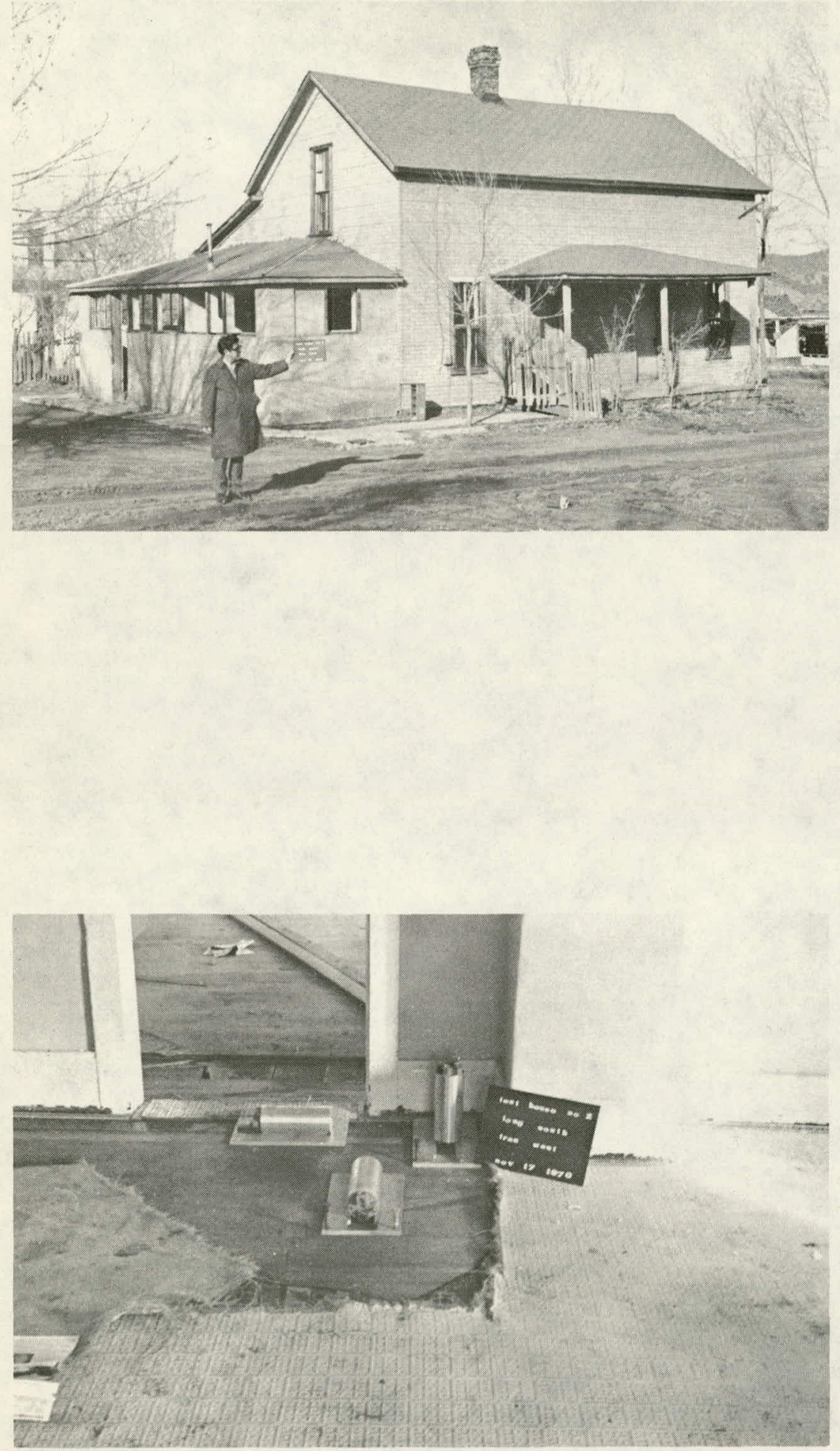

Photo \#5: Station \#2, Test House \#2, looking northwest.
Photo \#6: Station \#2, Test House \#2, seismometers on first floor, center of building. 


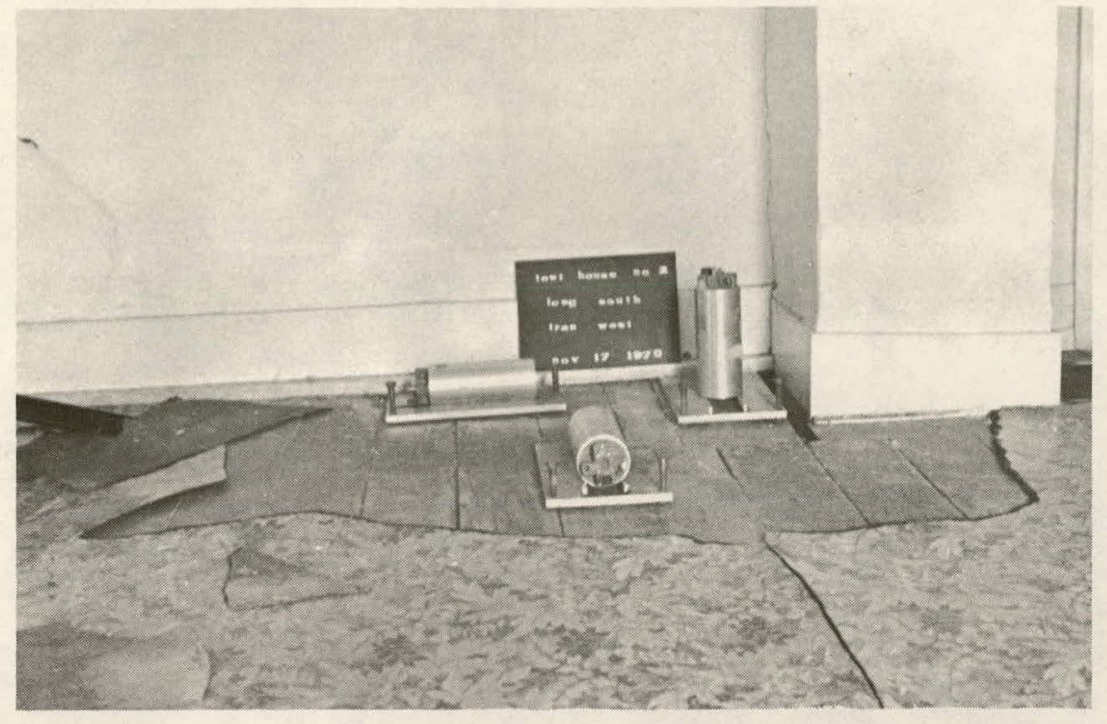

Photo \#7: Station \#2, Test

House \#2, Nov. 17, 1970.

Seismometers located second floor, center of building.

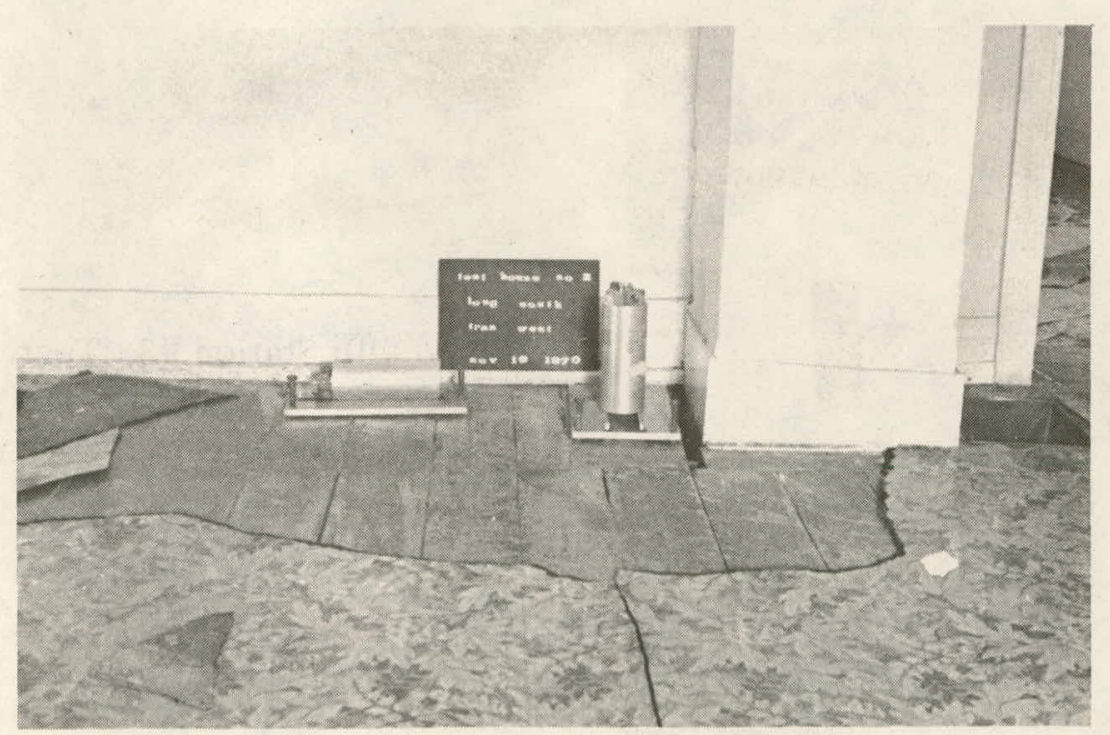

Photo \#8: Station \#2, Test House \#2, Nov. 19, 1970. Seismometer location on second floor, center. 

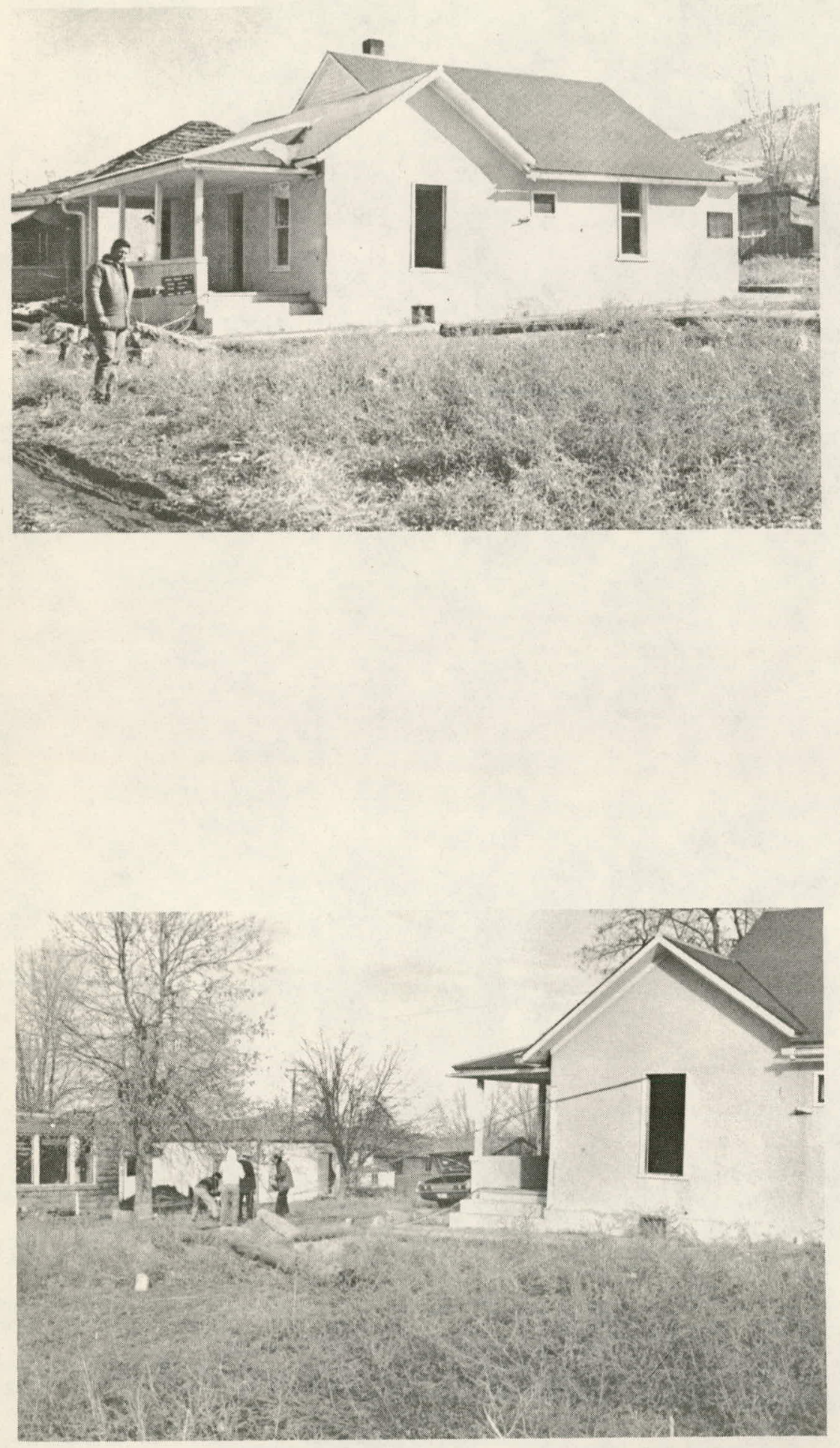

Photo \#9: Station \#3, Test House \#3, looking southeast.
Photo \#10: Station \#3, Test House \#3, typical pull test setup, pulling from the north side of the house. 

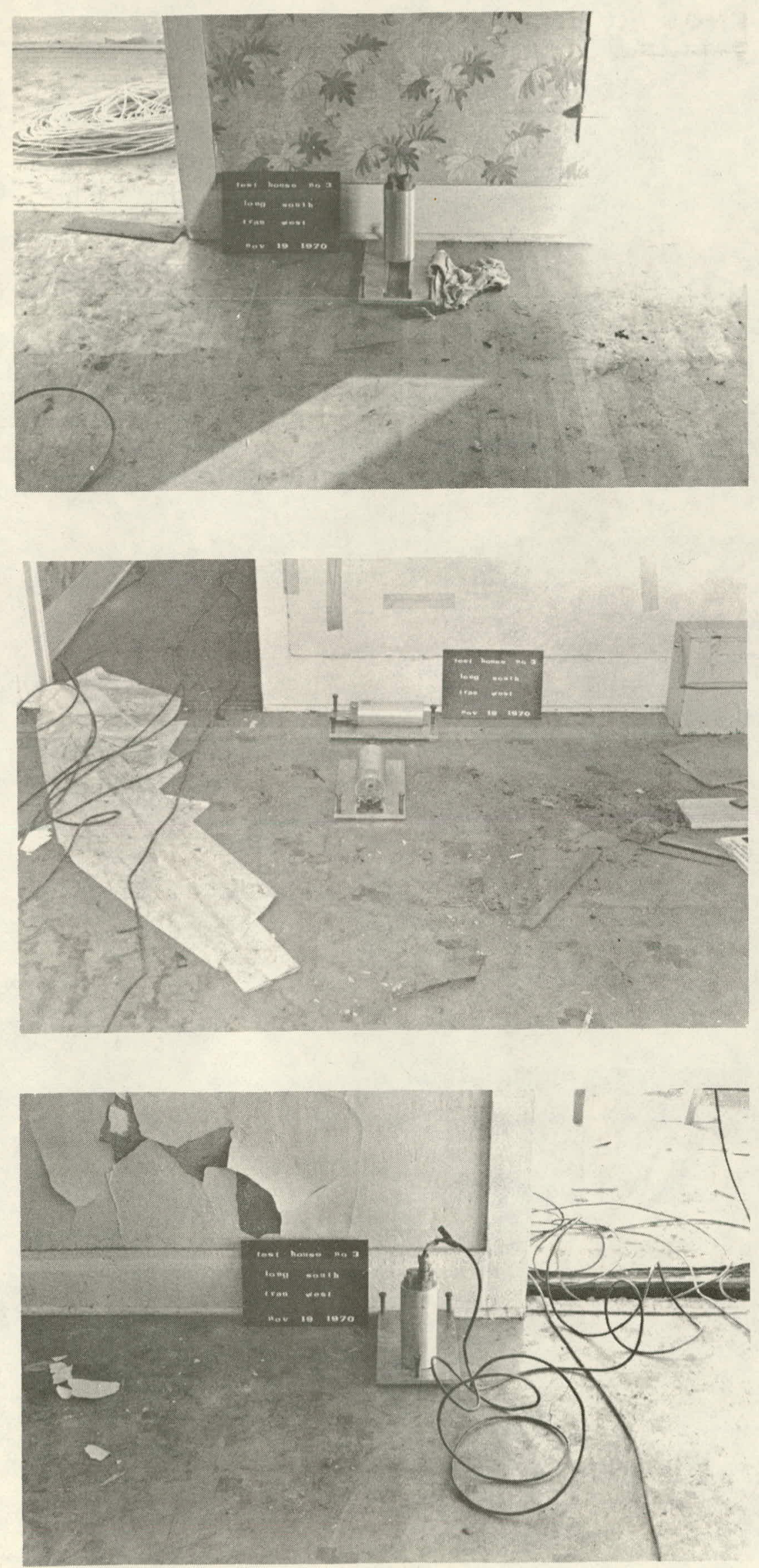

Photo \#1l: Station \#3, Test House \#3, seismometer location for Nov. 19, 1970 , first floor, north side of house.

Photo \#12: Station \#3, Test House \#3, seismometer location for Nov. 19, 1970, first floor center of house.

Photo \#13: Station \#3, Test House $¥ 3$, seismometer location for Nov. 19, 1970, first floor south of the house. 

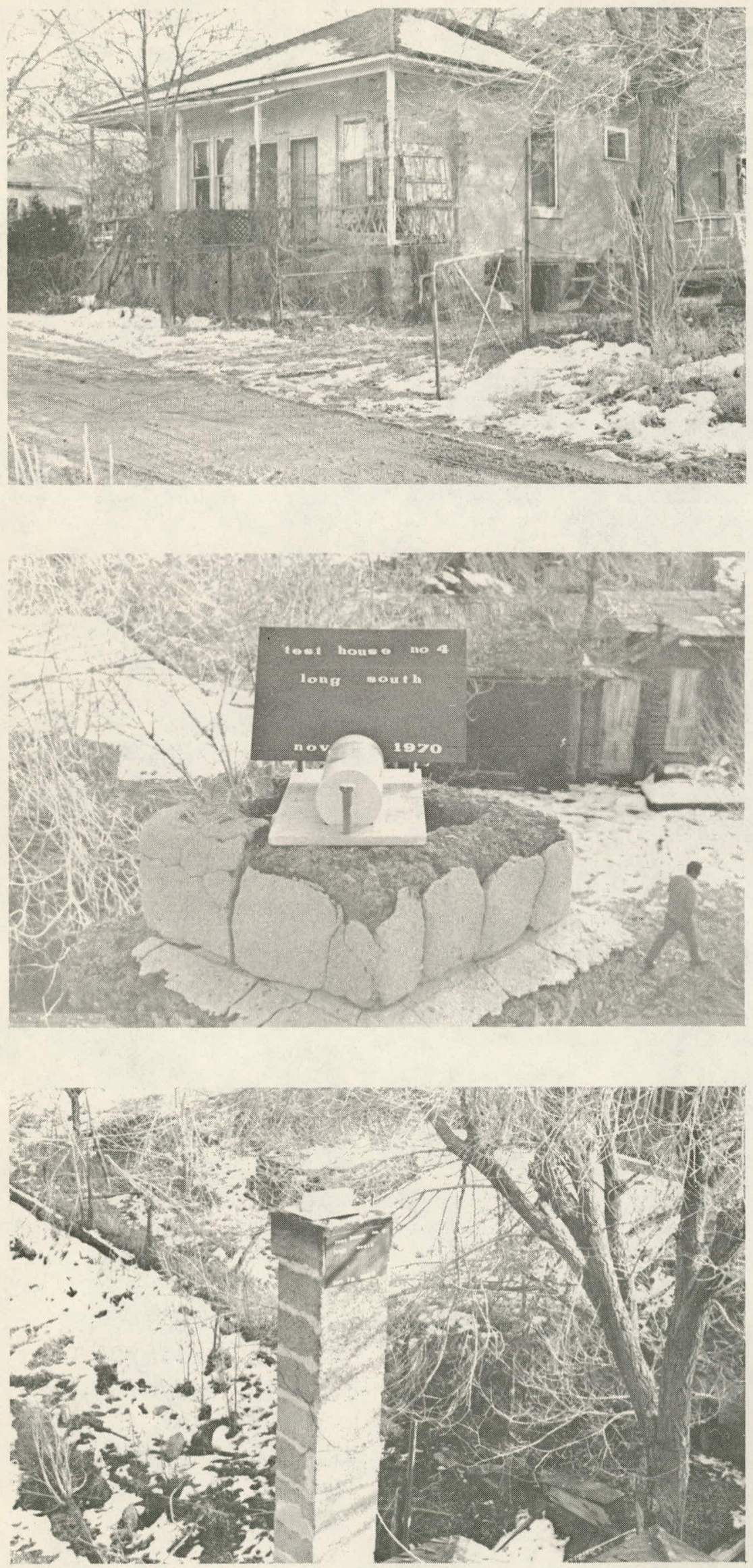

Photo \#14: Station \#4, Test House \#4, looking southeast.

Photo \#15: Station \#4, Test House \#4, seismometer location, center chimney of House \#4.
Photo \#16: Station \#4, Test House \#4, seismometer location, southeast chimney of House \#4. 

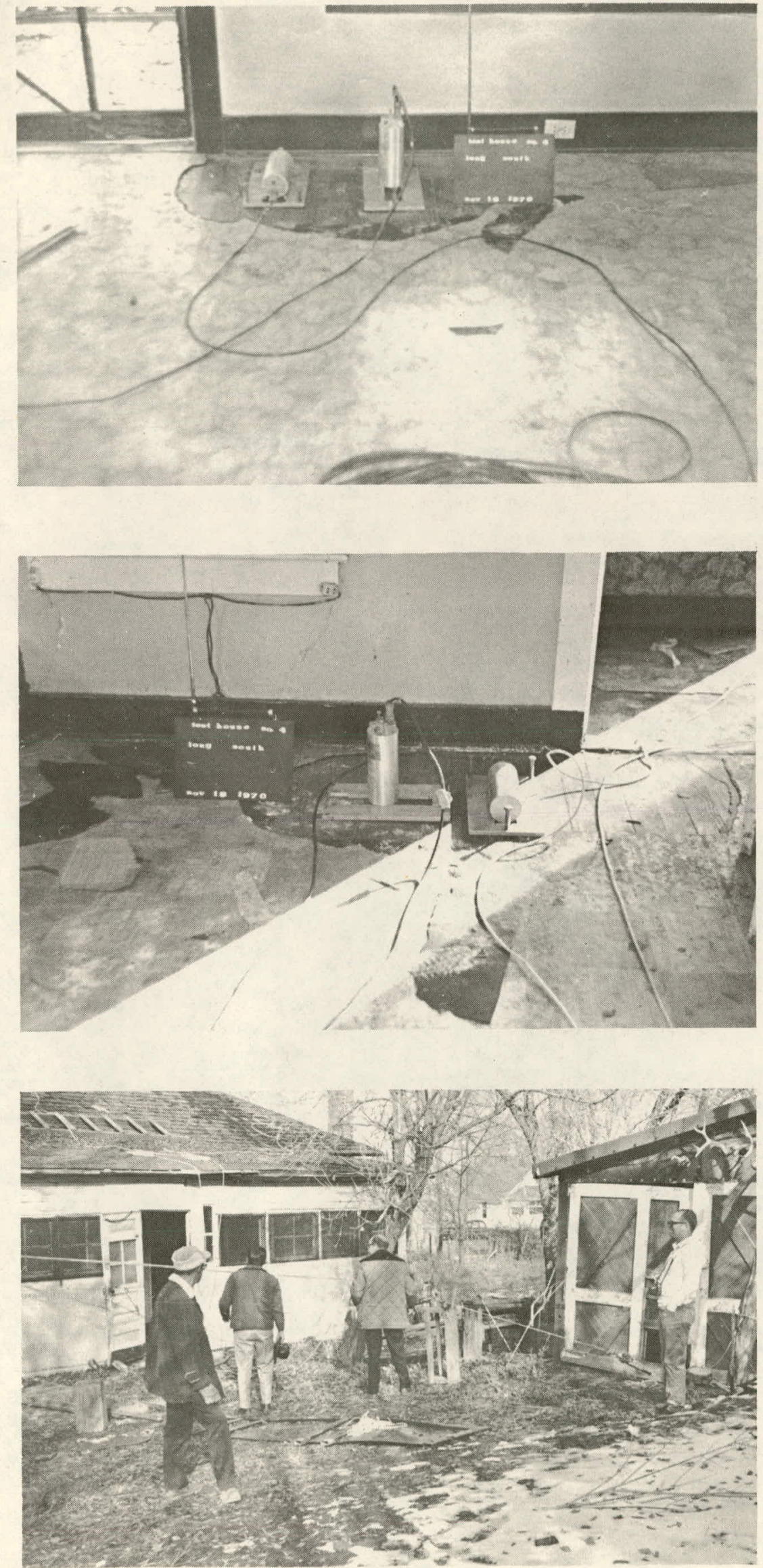

Photo \#17: Station \#4, Test House \#4, seismometer location, north side of house.
Photo \#18: Station \#4, Test House \#4, seismometer location, south side of house.
Photo \#19: Station \#4, Test House \#4, typical pull test setup, pulling from the south side of house 

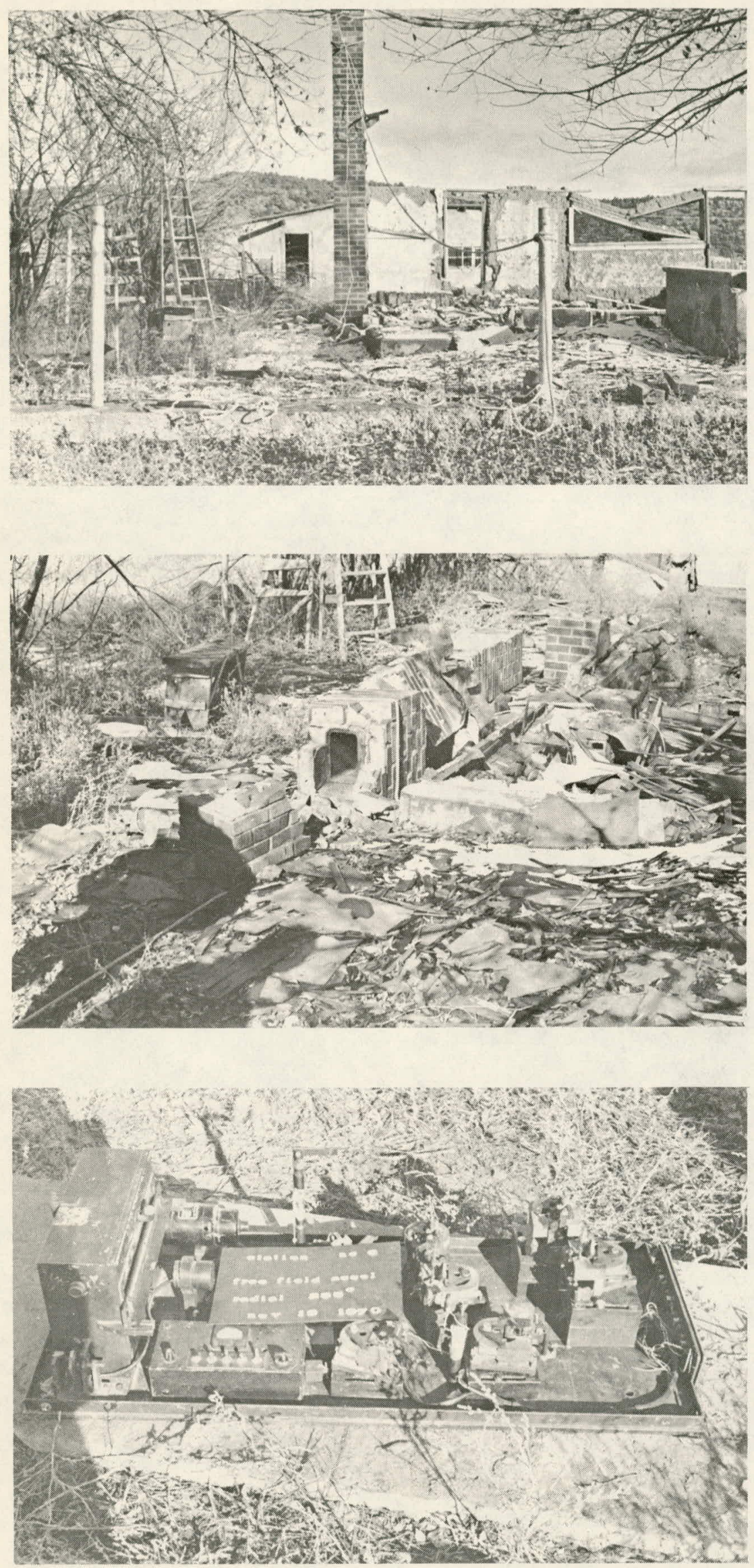

Photo \#20: Station \#5, looking north at free-standing chimney
Photo \#21: Station \#5, collapsed chimney after several pull tests.
Photo \#22: Station \#6(freefield station), uncovered accelerograph, 3 components of acceleration (two levels). 


\section{DISTRIBUTION}

J. R. Banister, Sandia Corp., Albuquerque, NM( 1 cory)

J. A. Blume, JABARD, San Francisco, CA (1 copy)

J. D. Carothers, LRL, Livermore, CA (1 copy)

D. U. Deere, University of Illinois, Urbana, IL (1 copy)

E. M. Douthett, AEC/NVOO, Las Vegas, NV (1 copy)

D. M. Ellett, Sandia Corp., Albuquerque, NM (l copy)

J. W. Hadley, LRL, Livermore, CA ( 1 copy)

W. W. Hays, ERC, Las Vegas, NV (2 copies)

W. Holley, Sandia Corp., Albuquerque, NM ( 1 copy)

L. S. Jacobsen, 267 Belgreen Place, Oakmont, Santa Rosa, CA ( 1 copy)

R. A. Johnson, AEC/NVOO, Las Vegas, NV ( 3 copies)

J. M. Keith, JABARD, San Francisco, CA (1 copy)

R. L. Kinnaman, AEC/NVOO, Las Vegas, NV (1 copy)

C. Kisslinger, St. Louis University, St. Louis, MO (1 copy)

R. R. Loux, AEC/NVOO, Las.Vegas, NV ( 1 copy)

W. V.. Mickey, NOAA7NOS, Rockville, MD (1 copy)

L. M. Murphy, NOAA/NOS, Rockville, MD (l copy)

N. M. Newmark, University of Illinois, Urbana, IL (l copy)

W. E. Ogle, LASL, Los Alamos, NM (l copy)

B. Redpath, NCG, Livermore, CA ( 1 copy)

A. Rembolt, NCG, Livermore, CA ( 1 copy)

R. E. Scholl, JABARD, San Francisco, CA (1 copy)

R.. E. Skjei, JABARD, San Francisco, CA (l copy)

A. D. Thornborough, AEC/NVOO, Las Vegas, NV (1 copy)

Col: W. Vandenberg, NCG, Livermore, CA ( 2 copies)

Col. R. West, U. S. Corps of Engineers, Albuquerque, NM (I copy)

S. D. Wilson, Shannon and Wilson, Inc.; Seattle, WA ( 1 copy)

Division of Technical Information Extension, U. S. Atomic Energy Commission, Oak Ridge, TN ( 2 copies)

Sandia Technical Libraries, Albuquerque, NM ( 2 copies)

'Technical: Library, AEC/NVOO, Las Vegas, NV ( 3 copies) 